\title{
Mobile Application for English Reading Comprehension
}

\author{
S Agustini ${ }^{1}$, N P Wardhani. ${ }^{1}$, M Kurniawan ${ }^{1}$, E N Amalina ${ }^{2}$ \\ ${ }^{1}$ Institut Teknologi Adhi Tama Surabaya, Indonesia \\ ${ }^{2}$ Universitas Nahdlatul Ulama Sidoarjo, Indonesia \\ sitiagustini@itats.ac.id
}

\begin{abstract}
Test of Teaching English of Foreign Language or TEFL is one of the scourges for students who must take this test for their graduation term. Many of them got a lack of motivation to learn, especially engineering students. Reading comprehension is one of the tests in TEFL test. However, many students failed in this section because they did not understand the text well and they had less of vocabulary. The students needed a mobile application which able to bring everywhere and they could learn the material and do the exercise anytime. Mobile application based on Android platform is the answer to help the students. In this application the students would learn the material of reading comprehension and do the exercise which divided into 3 levels; from the easier to the hardest.
\end{abstract}

\section{Introduction}

Indonesia is one of ASEAN Economic Community (AEC) members. The graduate students must be able to compete in this AEC to a better future. The ways to compete is improving their English ability. English is an international language which able to use foreigner to communication. That is why, many universities apply TOEFL test as a graduation requirement or as a requirement of final exam, thesis, or dissertation. They want their students or graduate students are able to compete with others. Every university has a different standard score as a requirement for the students to pass the test, unfortunately, not all of university has facilities to fill their students to do TOEFL Test. TOEFL test is to measurement someone skills to comprehend and apply American English. In TOEFL Test, there are three skills which are tested; listening comprehension, structure and written expression, and reading comprehension.

Many students need media to do TOEFL exercises because in their own university does not give facility to do it although their university decides TOEFL score as their requirement. This problem is being our purpose to do this research. The researchers want to give facility to the students to do TOEFL exercise or to improve TOEFL score by doing exercise in application which was made. This application would help the students to do exercise of those three skills in TOEFL. Before the students did do the exercise, they must understand the materials. The materials were also relating with the exercise. The materials given would help user understand reading comprehension easier.

Many students make many mistakes in reading comprehension. So, in this paper, the writers wanted to discuss about reading comprehension in TOEFL using application, but the TOEFL on our campus is TEFL (Teaching English of Foreign Language). Reading comprehension has the most important thing in the educational aspect, working, recreational, and social live [1]. In English teaching-learning process, the students ever get difficulty in learning especially in reading comprehension. Rahmawati stated that the problem is faced by the students in English text understanding is they lack to connect between a sentence and other sentences to find main idea and 
besides, the students have less information about the text given [2]. There another reason why the students get difficulty in teaching-learning English. the students gets less teaching-learning TOEFL materials in the class or teaching-learning process only do inside of the class. Erika et. al said that the students hard to understand the text because they have lack of vocabularies and reading technique [3]. The other problem is composed of cultural-based issues, English teaching and learning concerns, and contextual social problems [4].

The students need media to help them learn and to do the exercise which able they bring anywhere they go. The media must be efficient, flexible, and easy. One of the solutions is using e-learning by mobile learning application as a media. This way will interest the students to study everywhere and anytime. In this research, the researcher was planning and building TEFL application and the focus was on reading comprehension. The application was made based on Platform Android. This application aimed to help the students to increase their ability in reading comprehension.

\section{Related Works}

Today, several studies through English using mobile application have been developed. Ramya et.al was building a mobile application to build a mobile application to learn English as a second language [5]. That mobile application was Mobile Assisted Language Learning (MALL). The results of users' ability were increasing. Ahmet Basal et.al. made research through the effectiveness of applying mobile application in vocabulary learning [6]. The research was conducted by investigating the use of mobile application was more effective than traditional learning. The research showed that the post-test result was better than pre-test result. Maha et al [7] has done their study through students' satisfaction and performance to mobile application as a learning media. The respondents told their feeling by questioner given to the m-learning application.

\section{System Design}

\subsection{Description of System}

Application which was made in this research was a mobile application for English subject; TEFL exercises especially reading comprehension. This mobile application based on Android platform by implementing Android Studio and Java Program. This application was building for the students to understand reading material or exercise for TEFL test. The exercises had different levels; level 1, level 2, and level 3. Level 3 was the hardest exercise.

\subsection{Software Planning}

Planning of soft diagram could be seen in use case diagram. Use case diagram was used to describe the relation between use case and user. Figure 1 was use case diagram which was used in this research. There was only 1 user in use case diagram. That user was a student. There were two relation happened in use case diagram; the first relation was between student and LEARN and the second relation was between student and PRACTICE.

The function of use case LEARN is to show reading comprehension material. This use case had several choices; there were MAIN IDEA OF PASSAGE, PURPOSE OF PARAGRAPH, VOCABULARY, and INFERENCE. In this menu, there were few examples of practices through reading comprehension. Use case PRACTICE contained several exercises through reading comprehension. Those exercises consist of three levels and each level has 20 exercises with two reading texts. Those levels had different level of difficulties.

\subsection{Designing of User Interface Graphic}

Designing of main menu showed in figure 1 which has two choices; LEARN and PRACTICE menu. If the user chosen LEARN, there would appear the material should they learn. The topic divided into four kinds of topics; MAIN IDEA OF PASSAGE, PURPOSE OF PARAGRAPH, VOCABULARY, 


\section{ICATECH ITATS}

The $1^{\text {st }}$ International Conference on Advanced Engineering and Technology - 2018

INFERENCE. It has showed in figure 2. Therefore, PRACTICE menu chosen, it would be showed three levels of exercises; LEVEL 1, LEVEL 2, and LEVEL 3 like in figure 3.

Interaction between user and application system could be seen in figure 4. Users were students who could access 2 main things in the menu display. The beginning menu, the user would find LERAN and PRACTICE. In LEARN Menu, there were four parts; Main Idea of Passage, Purpose of Paragraph, Vocabulary, and Inference. Therefore, PRACTICE Menu contained exercise which divided into 3 levels.

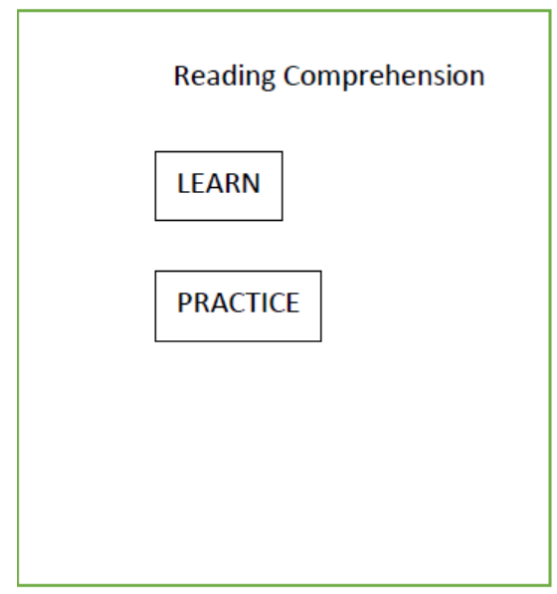

Figure 1. Display of Main Menu Application

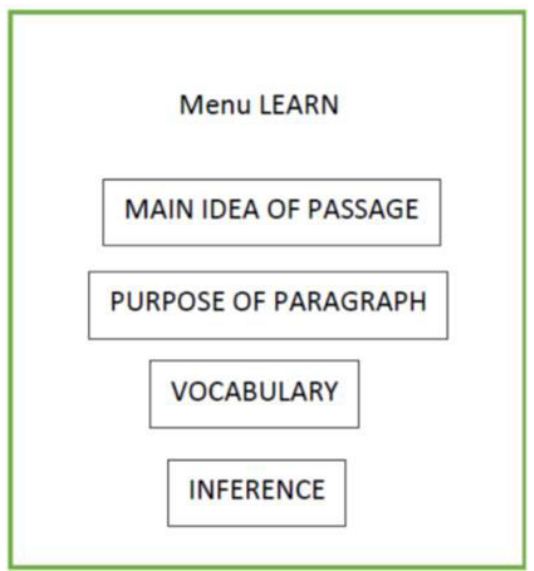

Figure 2. LEARN Menu

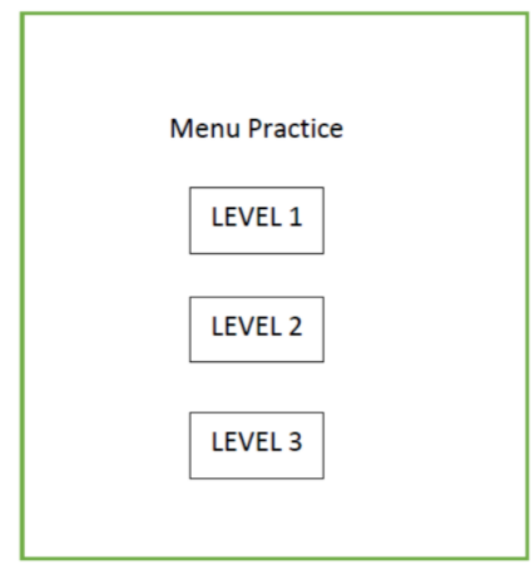

Figure 3. PRACTICE Menu 


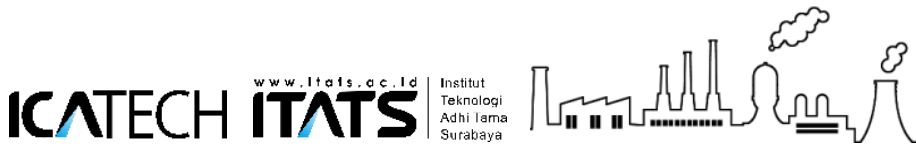

The $1^{\text {st }}$ International Conference on Advanced Engineering and Technology - 2018

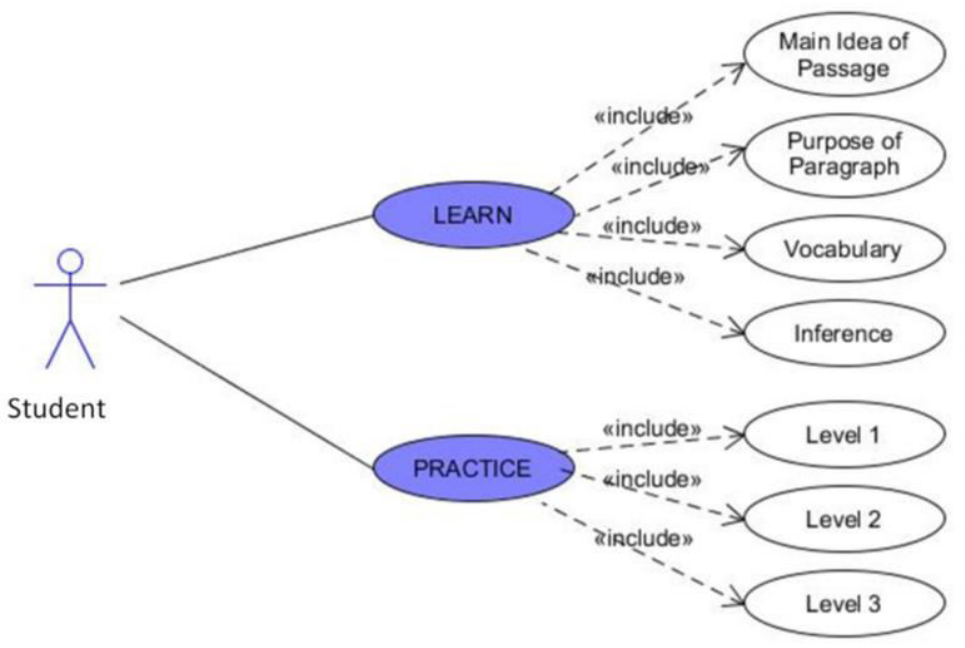

Figure 4. Use Case Diagrams

\section{Experiments and Analysis}

There are two main features in the first menu of this mobile application about TEFL materials and exercises. If the users chosen one of this, he/she would choose another menu from that features. The mobile application had tested few students. The testing of mobile application which has done using Android version 5.1 would be showed below:

Figure 5 was a display of main menu in this application. Main menu gave two choices, they were LEARN and PRACTICE. Menu LEARN contained materials about teaching reading comprehension and in PRACTICE menu consisted of TEFL exercises would be done by the students or users. If the users chosen LEARN Menu, there would be showed four topics through reading comprehension, such as main idea of passage, purpose of paragraph, vocabulary, and reference. Each topic was chosen, there was explanation and exercise with the answer. The aim of it, the students would be easier to understand and know the correct answer of the questions. The answer would be showed after the user answer the question given. Figure 6 was LEARN Menu and Figure 7 was PRACTICE Menu which consisted of exercise in 3 different levels. The difficulty level of practice questions was adjusted to the level of the question level. Level 1 was the easiest level and level 3 was the hardest level.

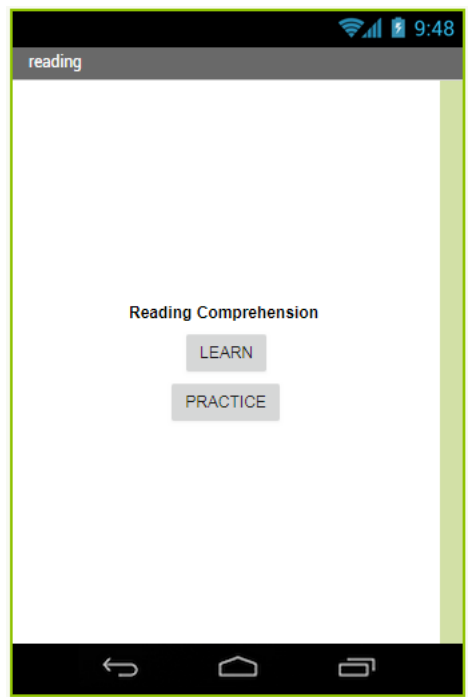

Figure 5. Main Menu 


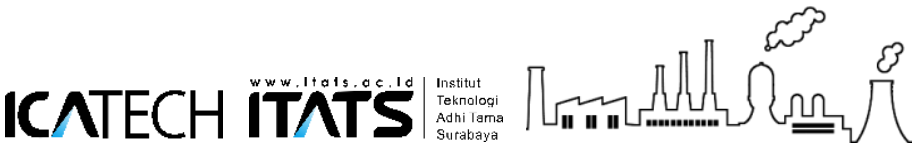

The $1^{\text {st }}$ International Conference on Advanced Engineering and Technology - 2018

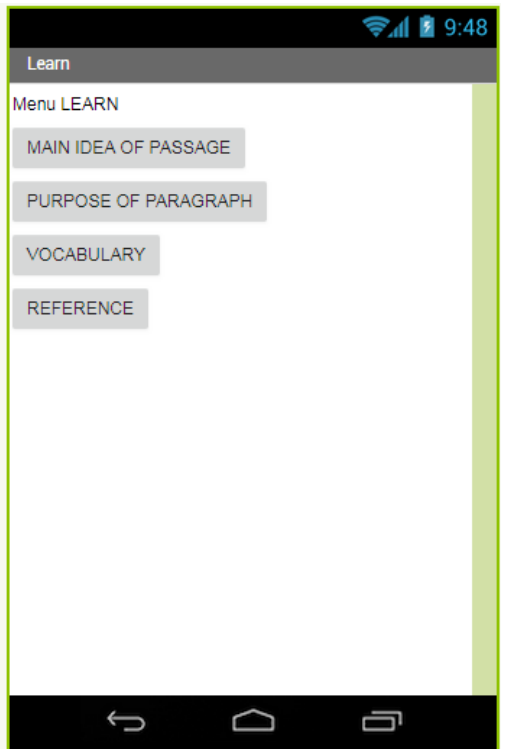

Figure 6. LEARN Menu

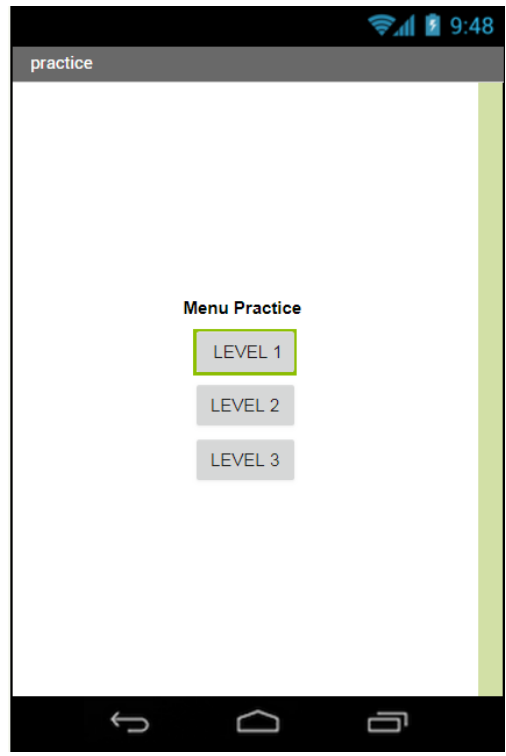

Figure 7. PRACTICE Menu

Figure 8 was a display of MAIN IDEA OF PASSAGE button. This application was not only giving materials but also the examples of the exercise based on the materials. Below of the exercise, the users ware also given the explanation about the question. Figure 8. a showed the exercise and the explanation about the answers.

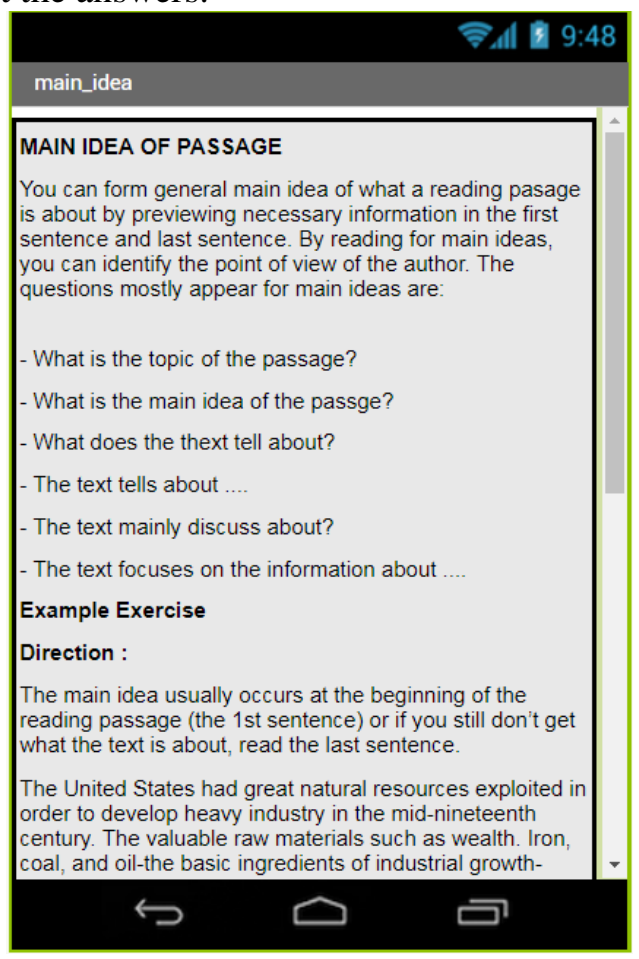

(a)

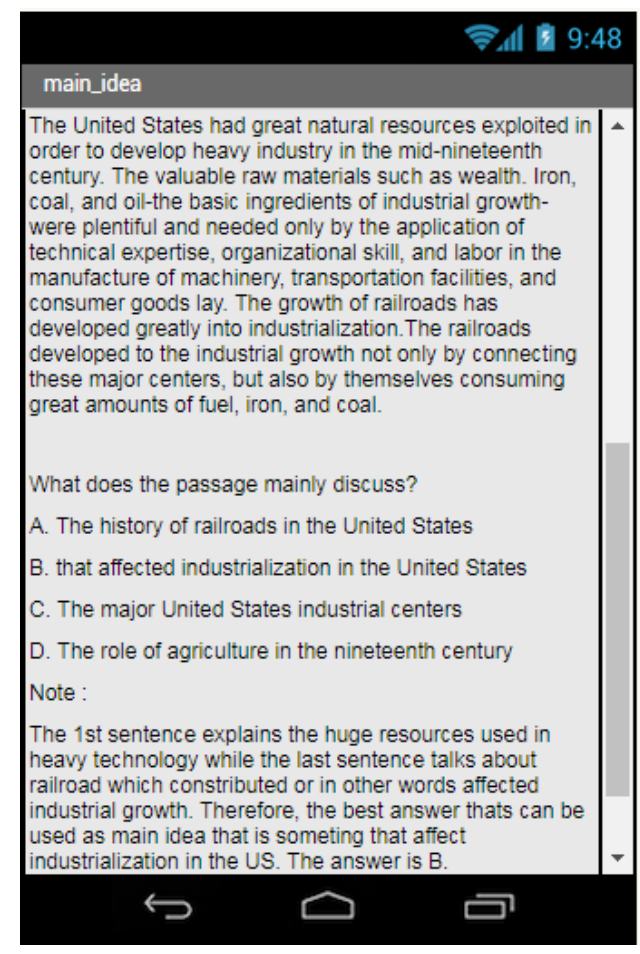

(b)

Figure 8. Menu of MAIN IDEA OF PASSAGE (a) topic explanation (b) exercise and explanation 


\section{ICATECH ITATS}

The $1^{\text {st }}$ International Conference on Advanced Engineering and Technology - 2018

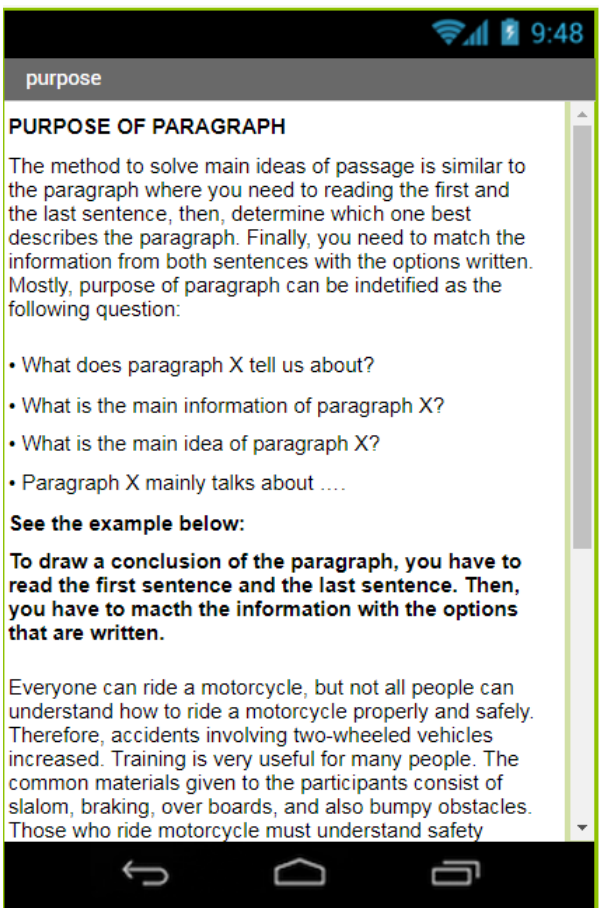

(a)

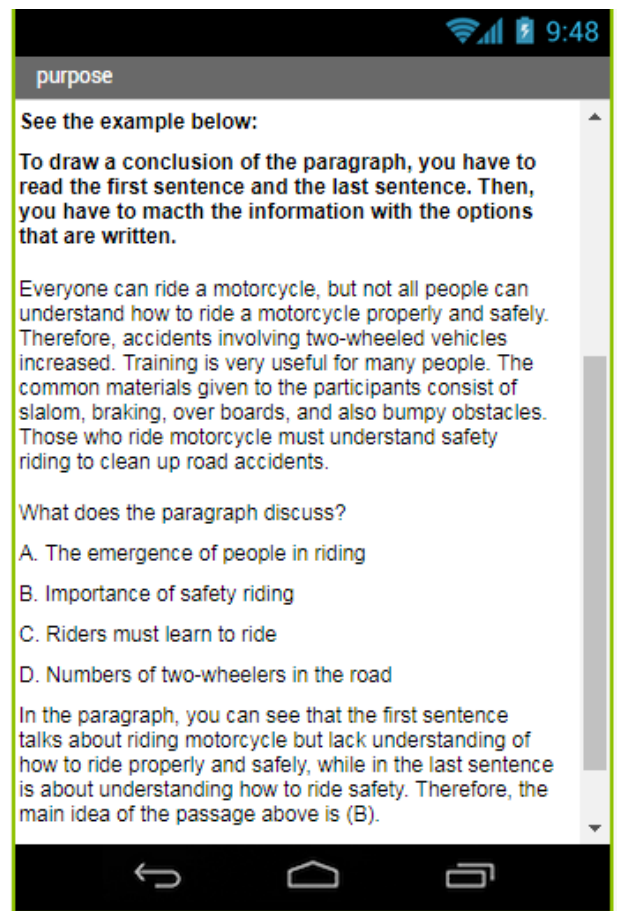

(b)

Figure 9. Menu of the Purpose of Paragraph (a) topic explanation (b) exercises and explanation

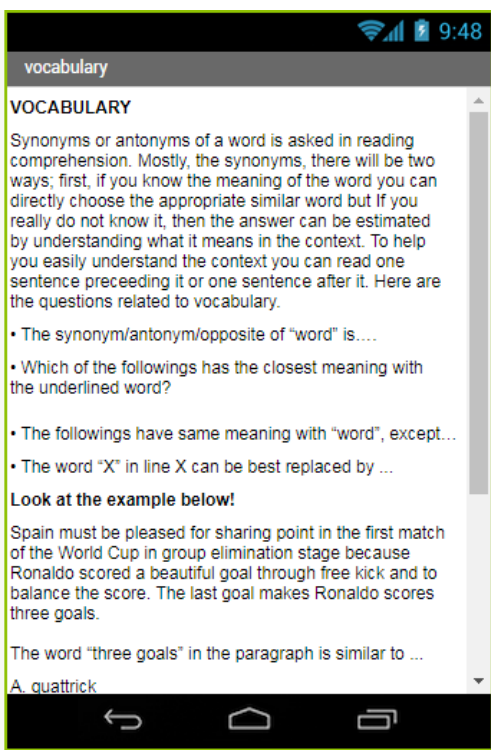

(a)

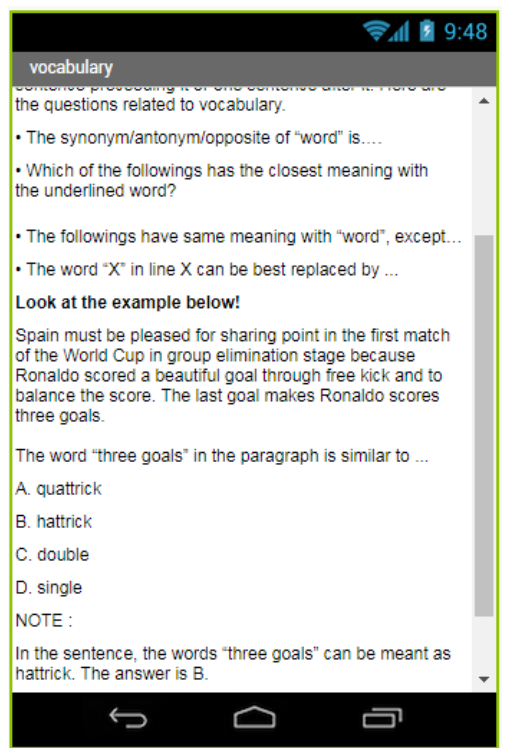

(b)

Figure 9. Vocabulary Menu (a) explanation about the topic (b) exercises and explanation

\section{Conclusion}

Today, mobile application was a technology which develops, especially in teaching learning process. Mobile application had advantages, such as this application was able to use everywhere and anytime. There was no reason for the students, if they couldn't learn because there was an application which helped them to learn easily. This application was running as planning and hopefully, this application would help the students to learn easily and they often to learn especially in reading comprehension. 


\section{ICATECH ITATS $=\operatorname{lom}$ M M}

The $1^{\text {st }}$ International Conference on Advanced Engineering and Technology - 2018

\section{References}

[1] A. R. M. Q. Radzuwan, "Reading Comprehension Difficulties among EFL Learners: The Case of First and Second Year Students at Yarmouk University in Jordan," Arab World English J., vol. 8 , no. 3, 2017.

[2] I. Rahmawati, "Improving Eighth Graders' Reading Comprehension through Autonomous Strategy," 2011.

[3] S. Erika, M. Sondang, and E. Rotua, "Improving Students' Reading Comprehension Achievement by Using K-W-L Strategy,” English Linguist. Res., vol. 4, no. 3, 2015.

[4] Suryanto, "An Investigation On English Reading Comprehension Problem In Indonesia Cultural Contexts," in The 1st International Conference on Education, Science, Art and Technology (the 1st ICESAT), 2017.

[5] G. Ramya and P. Madhumathi, "Review on Use of Mobile Apps for Language Learning," Int. J. Appl. Eng. Res., vol. 12, no. 21, 2017.

[6] B. Ahmet, Y. Selahattin, T. Asli, and S. Lutfiye, "Effectiveness of Mobile Applications in Vocabulary Teaching Contemporary Educational Technology," 2016.

[7] A. Maha and M. Heba, "Mobile Applications' Impact on Student Performance and Satisfaction," Online J. Educ. Technol., vol. 14, no. 4, 2015. 